\title{
Editorial: How to understand
}

Richard Ennals 
This could be described as a "Very Special Issue" of the European Journal of Workplace Innovation, based on a single major article by Allan Larsson. He is serving as personal adviser to the President of the European Commission on the European Pillar of Social Rights. The article we publish here is not part of his assignment, but the article has certainly benefited from his meetings with researchers and policymakers all across Europe.

Twenty years ago Allan Larsson, with a background of Swedish ministerial office, was Director-General for Employment and Social Affairs in the European Commission. Based on work with an advisory group, he issued the Green Paper "Partnership for a New Organisation of Work" in 1997, which led to numerous projects, involving many researchers who are contributors to and readers of the European Journal for Workplace Innovation. See issue 1.1 of EJWI for accounts of the significance of the Green Paper. Issues 2.1 and 2.2 present work which was partly inspired by the Green Paper, and the subsequent generation of practical projects. There were related policy developments on Social Partnership, Social Dialogue, Social Benchmarking, Open Co-ordination and Soft Law, linked by language from DG Employment and Social Affairs.

Larsson later took the same perspective to his work as adviser to the Director of the International Labour Organisation, which he linked to the United Nations Global Compact, which was launched in 2001. He advocated global alliances and development coalitions including UN agencies, universities, companies and NGOs. The UN Millennium Development Goals provided an overall structure, but he argued that coalition members would also gain from the experience of participation, securing collaborative advantage.

At the time of the Green Paper, Stephen Toulmin argued that the Green Paper was overly European in focus, and took insufficient account of the significance of globalisation. His book "Return to Reason" (Harvard 2001) set out some arguments that are echoed in Larsson's article. Toulmin identified myths of stability and equilibrium, and his work on demystifying economics helps us to understand the financial crash of 2008. Larsson provides a full and comprehensible account of the views of economists, going beyond what is typically taught in universities. The article will be valuable in preparing the new generation of economists and managers.

Projects following the Green Paper concentrated on the company level, and explored the development of collaboration and social partnership at regional level. In part this was because EU member states had control over their national policies in areas such as the economy and education. One way around this constraint was to talk in terms of regions and lifelong learning, where the member states did not claim control, and the European Commission could add value.

"How to understand" takes a remarkably contrasting approach addressing the global macroeconomic context in which business, work and learning take place in practical terms. It complements “The Social Pillar”, to be published by the European Commission.

The article tackles recent turbulence in many countries around the world, up to February 2017. It deals with Brexit (UK) and the election of President Trump (USA). We have not had a calm predictable environment for decision makers. There are threats to democracy and democratic institutions. Old ways of working may no longer be reliable. What is to be done? 
If the article is to contribute to bringing about sustainable change in an unpredictable world, it cannot stand alone. We will need accounts which draw on these geopolitical insights, but express issues and experience in terms of practical cases. Researchers from the time of the Green Paper continue to be active, individually and collectively, for example working in the European Workplace Innovation Network (EUWIN). They know that there is much more work to be done, making use of their earlier experience, and in a changing context.

The issues addressed in Larsson's article inevitably cross borders between several Directorates-General, as he considers Work and Learning in the European Social Pillar. There are examples from which we can learn, including in his native Småland, where Linnaeus University has developed a portfolio of courses which show that learning is about more than training, and can be based on reflection on experience. Sustainable Regional Development, for example, brought together Circles of mature students, concentrating their attention on local villages. Through the effective use of Dialogue Seminars, they reported, responded, and engaged in dialogue which wove a regional web of words and meanings, providing a new basis for collaboration with companies and municipalities. Crucially, the course was designed and delivered in partnership with the Student Union, who represent the human face of regional development.

Arguably, in this article Larsson has completed the picture, if we look back on his work. As a counter-balance to the global, we have the local, and indeed the meso level, as we build development coalitions. Larsson sets an example with his attention to the global. This is the European Journal of Workplace Innovation, but we should not restrict ourselves to a single continent. Practical collaboration can open up fresh opportunities.

At the end of the article Larsson makes it clear that he is handing over to a new generation of researchers and policy makers, to come up with new theories and policies. The article presents a knowledge base for policy discussions, rather than policy conclusions.

We hope that Allan Larsson's article will stimulate fresh debate, leading to articles in EJWI issues 3.2 and after. 